\title{
PENGUKURAN KEPUASAN NASABAH TERHADAP CUSTOMER SERVICE PADA PT BANK RAKYAT INDONESIA (PERSERO) Tbk, PEMBANTU KAYU TANGI BANJARMASIN
}

\author{
Nurchosyanti, Rika Novyanti, Novi Shintia \\ Jurusan Administrasi Bisnis, Prodi Administrasi Bisnis \\ Politeknik Negeri Banjarmasin \\ E-mail: Nurchosyanti01@gmai.com,ovi_green@yahoo.com,novi221177@poliban.ac.id
}

\begin{abstract}
Banks as financial services sector must absolutely pay attention to the quality of service to their customers. The service performed is a form of the best service provided by a bank to provide satisfaction to customers. The purpose of this study was to determine the level of customer satisfaction with the service of Customer Service of PT Bank Rakyat Indonesia (Persero) Tbk, the Banjarmasin branch of Kayu Tangi. This study uses a descriptive qualitative approach, which is to give an overview of the events studied so that it is easier for writers to get objective data in order to know and understand how employee motivation affects performance. The population in this study is the customer who made the main transaction in the Customer Service section of PT Bank Rakyat Indonesia (Persero) Tbk, Banjarmasin Tangi Wood Branch Office. Samples are taken randomly and are considered to represent the answers of all customers in the bank. The number of samples taken was 80 respondents. The results of this study indicate that the measurement of customer satisfaction with Customer Service at PT Bank Rakyat Indonesia (Persero) Tbk, Kayu Tangi Banjarmasin SubBranch Office still needs to be developed because there are some criticisms from customers of the servqual dimensions namely, Tangible, Reliability, Responsiveness, Assurance and Empaty.
\end{abstract}

Keywords: Customer Satisfaction, Customer Service, Service Quality, Customer and Service

\begin{abstract}
Abstrak
Bank sebagai sektor layanan jasa keuangan mutlak harus memperhatikan kualitas layanan terhadap nasabahnya. Pelayanan yang dilakukan adalah wujud pelayanan terbaik yang diberikan oleh suatu bank untuk memberikan kepuasan kepada nasabah. Adapun tujuan penelitian ini adalah untuk mengetahui tingkat kepuasan nasabah terhadap pelayanan Customer Service PT Bank Rakyat Indonesia (Persero) Tbk, Kantor Cabang Pembantu Kayu Tangi Banjarmasin. Penelitian ini menggunakan pendekatan kualitatif deskriptif, yaitu untuk memberi gambaran dari kejadian yang diteliti sehingga memudahkan penulis untuk mendapatkan data yang objektif dalam rangka mengetahui dan memahami bagaimana motivasi pegawai mempengaruhi kinerja. Populasi dalam penelitian ini adalah nasabah yang melakukan transaksi utama di bagian Customer Service. Sampel iambil secara acak dan dianggap dapat mewakili jawaban-jawaban dari semua nasabah yang terdapat di bank tersebut. Adapun jumlah sampel yang diambil adalah sebanyak 80 responden. Adapun hasil dari penelitian ini menunjukkan bahwa pengukuran kepuasan nasabah terhadap Customer Service pada PT Bank Rakyat Indonesia (Persero) Tbk, Kantor Cabang Pembantu Kayu Tangi Banjarmasin masih harus dikembangkan lagi karena terdapat beberapa kritik dari nasabah dari dimensi servqual yaitu, Tangibel, Reliability, Responsiveness, Assurance dan Empaty.
\end{abstract}

Kata kunci: Customer Satisfaction, Customer Service, Service Quality, Customer and Service 


\section{PENDAHULUAN}

Mendengar kata bank sebenarnya tidak asing lagi bagi kita, terutama yang hidup diperkotaan. Bahkan, dipedesaan sekalipun saat ini kata bank bukan merupakan kata yang asing dan aneh. Menyebut kata bank setiap orang selalu mengaitkannya dengan uang sehingga selalu

saja ada anggapan bahwa yang berhubungan dengan bank selalu ada kaitannya dengan uang. Hal ini tidak salah karena bank memang merupakan lembaga keuangan atau perusahaan yang bergerak di bidang keuangan. Sebagai lembaga keuangan bank menyediakan berbagai jasa keuangan. Di negara-negara maju bank bahkan sudah merupakan kebutuhan utama bagi masyarakat setiap kali bertransaksi.

Dalam menjalankan aktivitas perbankan dibutuhkan teknisi khusus sesuai dengan bidangnya, salah satu contoh customer service atau yang sering kita dengar sebagai seseorang yang melayani nasabah. Untuk menarik nasabah dilakukan berbagai cara diantaranya melalui pelayanan yang diberikan seorang customer service seperti memberikan pelayanan yang cepat dan tepat.

Dimana terjadi perbandingan yang tidak seimbang antara banyaknya nasabah dengan jumlah petugas customer service yang ada. Untuk itu seorang customer service dituntut untuk menarik, cekatan, profesional serta dapat berkomunikasi dengan nasabah dengan baik, agar nasabah dan calon nasabah merasa puas terhadap pelayanan yang diberikan oleh customer service kepadanya. Keberhasilan strategi pemasaran dapat dicapai dengan kepuasaan nasabah yang telah terpenuhi. Adapun kepuasaan nasabah yang ternyata dapat juga mempengaruhi omset penjualan yang dihasilkan. Jika nasabah merasa puas dalam produk yang diinginkan maka permintaan akan meningkat dan omset yang penjualan akan naik. Namun, jika nasabah tidak merasa puas permintaan pun akan menurun begitu juga dengan omset penjualannya.

Untuk mengetahui bagaimana pelayanan yang diberikan Customer Sevice (CS) PT Bank Rakyat Indonesia (Persero) Tbk, KCP Kayu Tangi Banjarmasin penulis beberapa waktu lalu telah melakukan wawancara dengan pihak PT Bank Rakyat Indonesia (Persero) Tbk, KCP Kayu Tangi Banjarmasin dan membagikan kuesioner kepada 80 nasabah di kantor PT Bank Rakyat Indonesia (Persero) Tbk, KCP Kayu Tangi Banjarmasin. Dari uraian di atas, penulis hendak melakukan penelitian tentang perilaku customer service kepada nasabah dengan mengambil judul : "Pengukuran Kepuasaan Nasabah Terhadap Customer Service pada PT Bank Rakyat Indonesia (Persero) Tbk, Kantor Cabang Pembantu Kayu Tangi Banjarmasin". Agar permasalahan dalam penelitian ini tidak menyimpang dan untuk lebih memperjelas masalah yang akan di uraikan, maka penulis membatasi masalah yang pada pengukuran kepuasan nasabah terhadap Customer Service pada PT Bank Rakyat Indonesia (persero) Tbk, Kantor Cabang Pembantu Kayu Tangi Banjarmasin.

Agar permasalahan dalam penelitian ini tidak menyimpang dan untuk lebih memperjelas masalah yang akan di uraikan, maka penulis membatasi masalah yang pada pengukuran kepuasan nasabah terhadap Customer Service pada PT Bank Rakyat Indonesia (persero) Tbk, Kantor Cabang Pembantu Kayu Tangi Banjarmasin.

Untuk lebih fokus dalam pembahasan, rumusan masalah pada penelitian ini adalah utuk mengetahui tingkat kepuasan nasabah terhadap pelayanan Customer Service PT Bank Rakyat Indonesia (Persero) Tbk, Kantor Cabang Pembantu Kayu Tangi Banjarmasin. 


\section{TINJAUAN PUSTAKA}

Pengertian Kepuasan Nasabah

Kepuasan nasabah menjadi fokus perhatian oleh setiap pelaku bisnis, dimana tingkat kepentingan dan harapan nasabah serta pelaksanaan atau kinerja yang dilakukan perusahaan haruslah sesuai. Pada hakekatnya menurut Philip Kotler (2002) kepuasan nasabah menjelaskan bahwa perasaan senang atau kecewa seseorang yang berasal dari perbandingan antara kesannya terhadap kinerja (hasil) suatu produk dan harapanharapannya. Pendapat ini sama halnya dengan pendapatan yang dikemukakan oleh Tse dan Wilton (1988) yang menyatakan bahwa kepuasan atau ketidakpuasan pelanggan merupakan respon konsumen terhadap evaluasi ketidaksesuaian yang dirasakan antara harapan sebelumnya dan kinerja aktual produk setelah pemakaiannya. Kepuasan nasabah juga merupakan modal dasar untuk membentuk loyalitas yang bisa dijadikan sebagai salah satu senjata untuk menaikan keunggulan bersaing suatu perusahaan yang bergerak di sektor jasa. Mulanya konsep kepuasan dapat didefinisikan sebagai kepuasan yang terjadi setelah pertimbangan evaluasi pilihan yang memperhatikan pada keputusan pembelian (Churchill dan Saupreyangt, 1992; Smith dan Wright, 2004).

\section{Faktor-Faktor yang mempengaruhi}

Kepuasan Pelanggan menurut ahli.

Zeithmal dan Bitner

mengemukakan bahwa kepuasan adalah konsep yang jauh lebih luas dari hanya sekedar penilaian kualitas pelayanan, namun juga dipengaruhi oleh faktor-faktor lain yang dapat dijelaskan sebagai berikut:

1. Kualitas pelayanan atau jasa, yaitu konsumen akan merasa puas apabila mereka mendapatkan pelayanan yang baik atau sesuai dengan yang diharapkan.
2. Kualitas produk, yaitu konsumen akan merasa puas apabila hasil mereka menunjukkan bahwa produk yang mereka gunakan berkualitas.

3. Harga, yaitu produk yang mempunyai kualitas yang sama tetapi menetapkan harga yang relatif murah akan memberikan nilai yang lebih tinggi kepada konsumen.

4. Faktor situasi, yaitu keadaan atau kondisi yang dialami oleh konsumen.

5. Faktor pribadi dari konsumen, yaitu karakteristik konsumen yang mencakup kebutuhan pribadi.

\section{Prinsip-prinsip Kualitas Pelayanan}

Untuk dapat menyelenggarakan menejemen pelayanan dengan baik, kita harus mengelola moment kritis pelayanan, berempati kepada konsumen dengan cara membuat lingkaran pelayanan dan menghindari terjadinya gap. Selain itu ada juga prinsip-prinsip manajemen pelayanan yang dapat dipakai sebagai bahan acuan. Adapun Prinsip-prinsip tersebut menurut Raminto dan Winarsih (2008 ; 87) antara lain:

a. Identifikasi kebutuhan konsumen yang sesungguhnya.

b. Sediakan pelayanan yang terpadu (onestop-shop).

c. Membuat system yang mendukung pelayanan konsumen.

d. Usahakan agar semua orang atau karyawan bertanggung jawab terhadap kualitas pelayanan.

e. Layanilah keluhan konsumen secara baik.

f. Terus berinovasi.

g. Karyawan adalah sama pentingnya dengan konsumen.

h. Bersikap tegas tetapi ramah terhadap konsumen.

i. Jalin komunikasi dan interaksi khusus dengan pelanggan atau nasabah dan

j. Selalu mengontrol kualitas. 
Pengertian Pengukuran Kepuasan Nasabah

Berdasarkan pengertian yang ada dapat disimpulkan, bahwa kepuasan pelanggan merupakan kesetiaan konsumen terhadap perusahaan atau suatu produk tertentu dengan disertai tindakan untuk membeli kembali dan konsumen bersedia mengembangkan hubungan kembali.

Dalam menentukan seberapa besar kepuasan nasabah terhadap suatu bank dapat dilakukan dengan berbagai cara. Menurut Kotler (Kasmir, 2008: 163) pengukuran kepuasan pelanggan dapat dilakukan melalui empat sarana, yaitu:

a. Sistem keluhan dan usulan artinya seberapa banyak keluhan atau complain yang dilakukan nasabah dalam suatu periode, makin banyak berarti makin kurang baik.

b. Survei kepuasan konsumen. Dalam hal ini bank perlu secara berkala melakukan survei baik melalui wawancara maupun kusioner tentang segala sesuatu yang berhubungan dengan bank tempat nasabah melakukan transaksi selama ini. Untuk itu perlu adanya survei kepuasan konsumen.

c. Konsumen samara, bank dapat mengirim karyawannya atau melalui orang lain untuk berpura-pura menjadi nasabah guna melihat pelayanan yang diberikan oleh karyawan bank secara langsung, sehingga terlihat jelas bagaimana karyawan melayani nasabah sesungguhnya.

d. Analisis mantan pelanggan. Dengan melihat catatan nasabah yang pernah menjadi nasabah bank guna mengetahui sebab-sebab mereka tidak lagi menjadi nasabah bank kita.

\section{Fungsi dan Tugas Customer Service}

Customer Service tentu memiliki fungsi dan tugas yang harus di embannya. Fungsi dan tugas yang harus dilaksanakan dalam arti dapat dilaksanakan dengan sebaik-baiknya dan bertanggung jawab dari awal sampai sesuatu pelayanan. Fungsi dan tugas Customer Service yang harus benar-benar dipahami sehingga seorang Customer Service dapat menjalankan tugasnya secara prima. Menurut (Kasmir, 2004: 203) fungsi dan tugas Customer Service, sebagai berikut

1. Sebagai resepsionis

Tugas Customer Service sebagai resepsionis adalah menerima tamu yang datang dengan ramah, sopan, tenang, simpatik, menarik dan menyenangkan.

2. Sebagai deskman

Tugas Customer Service sebagai deskman antara lain memberikan informasi, menjelaskan manfaat dan ciriciri produk, menjawab pertanyaan pelanggan mengenai produk serta membantu pelanggan yang membutuhkan pertolongan seperti mengisi formulir.

3. Sebagai salesman

Tugas Customer Service sebagai salesman adalah menjual prodok, melakukan crossselling, mengadakan pendekatan dan mencari pelanggan yang baru, berusaha membujuk pelanggan yang baru dan berusaha untuk mempertahankan pelanggan yang lama, serta berusaha mengatasi setiap permasalahan yang dihadapi oleh pelanggan, termasuk keberatan dan keluhan pelanggan.

4. Sebagai Customer Relation Officer

Sebagai Customer Relation Officer, tugas seorang Customer Service adalah menjaga image atau cita perusahaan..

5. Sebagai komunikator

Sebagai komunikitor, tugas seorang Customer Service adalah memberikan segala informasi dan kemudahan kepada pelanggan di samping itu juga sebagai tempat menampung dalam pelayanan di bank tersebut. Customer Service juga 
mempunyai tanggung jawab dalam menjalankan tugasnya.

\section{METODE PENELITIAN}

\section{Jenis Penelitian}

Dalam penelitian ini penulis menggunakan pendekatan kualitatif dimana dalam penelitian yang dilakukan bersifat deskriptif, yaitu untuk memberi gambaran dari kejadian yang diteliti sehingga memudahkan penulis untuk mendapatkan data yang objektif dalam rangka mengetahui dan memahami bagaimana motivasi pegawai mempengaruhi kinerja (Sukmadinata, 2006:72).

\section{Lokasi dan waktu Penelitian}

Lokasi penelitian adalah area dengan batasan yang jelas agar tidak menimbulkan kekaburan dengan kejelesan daerah untuk wilayah tertentu. Karena PT.BANK RAKYAT INDONESIA (Persero) Tbk. Kantor Cabang Pembantu Kayu Tangi Banjarmasin ini berada di kota yang banyak orang-orang sudah mengetahui

\section{Populasi dan Ukuran Sampel Penelitian}

Populasi dalam penelitian ini adalah nasabah yang melakukan transaksi utama di bagian Customer Service pada PT Bank Rakyat Indonesia (persero) Tbk, Kantor Cabang Kayu Tangi Banjarmasin.

Sampel yang merupakan bagian dari populasi yang di teliti. Sampel dianggap sebagai perwakilan dari populasi yang hasilnya mewakili keseluruhan gejala yang di amati. Ukuran dan keragaman sampel menjadi penentuan baik tidaknya sampel yang di ambil. Adapun jumlah sampel yang diambil adalah sebanyak 80 responden.

\section{Teknik Pengumpulan Data}

1. Wawancara

Penulis melakukan wawancara atau tanya jawab secara bertatap muka dengan Customer Service di bank tersebut. Dari hari wawancara dapat diperoleh gambaran permasalahan yang sedang di hadapi oleh Bank BRI Kantor Kayu Tangi Banjarmasin.

2. Observasi

Penulis melakukan pengumpulan data dengan mengamati objek yang di teliti secara langsung yaitu kegiatan Customer Service. Dalam mengukur kepuasan nasabah pada Customer Service di Bank BRI Kantor Kayu Tangi Banjarmasin.

3. Kuesioner

Kuesioner sebagai alat bantu pengumpulan data yang disajikan dalam bentuk pertanyaan terkait dengan pelayanan yang diterima, sehingga responden dapat memberikan penilaian terhadap pelayanan yang diterima dan responden dapat memberikan jawaban atas pertanyaan secara tertulis tentang service quality yang diberikan oleh Customer Service.

4. Dokumentasi

Dalam penelitian ini, dokumen yang diperoleh dari PT Bank BRI Kantor Kayu Tangi Banjarmasin, terutama yang berkenaan dengan perusahaan, struktur organisasi beserta uraian tugasnya dan dokumen lain yang berkenaan langsung dengan penelitian tersebut.

\section{Metode Analisis Data}

Teknik analisis ini yang di gunakan dalam penelitian adalah teknik data yang non statistik, yaitu data yang tidak menggunakan rumusan statistik.

Data dan informasin yang di peroleh dari perusahaan berhubungan dengan penelitian ini di analisis secara deskriptif. Penulis mempergunakan metode analisis deskriptif, yaitu data yang diperoleh akan dipilih dan disusun dengan sistematis kemudian dianalisa kembali berdasarkan kajian teori untuk mendapatkan deskripsi tentang pengukuran kepuasan nasabah terhadap Customer Service 
pada PT Bank Rakyat Indonesia (persero) Tbk, Kantor Cabang Pembantu Kayu Tangi Banjarmasin.

\section{HASIL DAN PEMBAHASAN}

Analisis dan Pemecahan Masalah

Pengukuran kepuasan nasabah dalam meningkatkan pelayanan dalam bidang usaha sangatlah penting, tidak terkecuali perusahaan perbankan untuk keperluan strategi yang tepat agar dalam persaingan bisnis, pelayanan dapat memberikan pengaruh yang sangat baik guna mempertahankan nasabah yang lama maupun yang baru. Salah satu layanan yang di berikan oleh bank adalah pelayanan dibagian Customer Service. Oleh sebab itu, layanan pada Customer Service yang ada di Bank haruslah baik guna untuk membuat nasabah merasa puas atas layanan yang didapatkannya.

\section{Bukti Masalah}

Bukti masalah dari penelitian ini penulis menemukan bukti bahwa saat jam kerja seorang Customer Service pada Bank Rakyat Indonesia KCP Kayu Tangi Banjarmasin.

\section{Akibat Masalah}

Pelayanan kantor BRI tak memuaskan nasabah. Salah satunya, komunikatif seorang Customer Service di KCP Kayu Tangi Banjarmasin.

Untuk mengetahui pengukuran kepuasan nasabah yang telah dilaksanakan pada bagian Customer Service PT Bank Rakyat Indonesia (Persero) Tbk. Kantor Cabang Pembantu Kayu Tangi Banjarmasin serta tanggapan nasabah terhadap layanan yang diberikan maka penulis mengambil 80 responden untuk menjadi subjek penelitian.

Berikut ini adalah profil responden berdasarkan jenis kelamin dan usia, serta tanggapan responden berdasarkan dimensi kualitas, seperti tangibility, reability, responsiveness, assurance, dan empathy.

Tabel 1. Jenis Kelamin Responden

\begin{tabular}{|c|c|c|c|}
\hline No. & Keterangan & Jumlah & Presentase \\
\hline 1. & Laki-laki & 45 & $56,25 \%$ \\
\hline 2. & Perempuan & 35 & $43,75 \%$ \\
\hline \multicolumn{2}{|c|}{ Jumlah } & $\mathbf{8 0}$ & $\mathbf{1 0 0 \%}$ \\
\hline
\end{tabular}

Sumber : Data diolah Tahun 2018

Tabel 2. Usia Responden

\begin{tabular}{|c|c|c|c|}
\hline No. & Keterangan & Jumlah & Presentase \\
\hline 1. & $<25$ tahun & 44 & $55 \%$ \\
\hline 2. & 25 s/d 34 tahun & 22 & $27,5 \%$ \\
\hline 3. & 35 s/d 44 tahun & 10 & $12,5 \%$ \\
\hline 4. & $>44$ tahun & 4 & $5 \%$ \\
\hline \multicolumn{2}{|c|}{ Jumlah } & $\mathbf{8 0}$ & $\mathbf{1 0 0 \%}$ \\
\hline
\end{tabular}

Sumber : Data diolah Tahun 2018

Berdasarkan tabel 1 tentang jenis kelamin responden dapat dilihat bahwa responden laki-laki lebih banyak dari pada responden perempuan, yaitu responden lakilaki sebanyak 56,25\% (45 responden) dan responden perempuan sebanyak 43,75\% (35 responden). Dari responden tersebut dapat dikemukakan bahwa mayoritas nasabah yang ada di PT Bank Rakyat indonesia (Persero) Tbk Kantor Cabang Pembantu Kayu Tangi Banjarmasin adalah laki-laki. 
Berdasarkan dari table 2 usia diatas, pembagian usia responden PT Bank Rakyat indonesia (Persero) Tbk, Kantor Cabang Pembantu Kayu Tangi Banjarmasin ini terbagi dengan banyak perbedaan, karena ada selisih yang banyak antara responden muda maupun tua. Dari data tersebut dapat dikemukakan bahwa sebagian besar nasabah di PT Bank Rakyat indonesia (Persero) Tbk, Kantor Cabang Pembantu Kayu Tangi Banjarmasin berada di rentang usia $<25$ tahun.

\section{Tangibles (Bukti Langsung)}

Berdasarkan tabel 3 dengan jumlah 80 responden dapat diketahui bahwa 75\% ( 60 responden ) menjawab sangat baik, 12,5\% ( 10 responden ) menjawab baik, 6,25\% (5 responden) menjawab cukup baik, dan $6,25 \%$ (5 responden) menjawan tidak baik hal ini kerapian di meja seorang Customer Service perlu ditingkatkan lagi agar nasabah merasa nyaman terhadap layanan yang diterima pada PT Bank Rakyat Indonesia (Persero) Tbk, Kantor Cabang Pembantu Kayu Tangi Banjarmasin.

Berdasarkan tabel 4 dengan jumlah 80 reponden dapat diketahui bahwa 50\% (40 responden) yang menyatakan sangat baik, $18,75 \%$ (15 responden) yang menyatakan baik, $18,75 \%$ (15 responden) yang menyatakan cukup baik dan 12,5\% (10 responden) yang menyatakan tidak baik, perlu ditingkat lagi cara berpakaiannya seorang Customer Service yang bersih dan rapi. Dengan demikian dapat disimpulkan bahwa $50 \%$ responden menyatakan cara berpakian Customer Service pada PT Bank Rakyat Indonesia (Persero) Tbk, Kantor Cabang Pembantu Kayu Tangi Banjarmasin.

Tabel 3. Tanggapan responden tentang kelengkapan formulir aplikasi.

\begin{tabular}{|c|c|c|c|}
\hline No & Keterangan & Jumlah & Presentase \\
\hline 1 & Sangat Baik & 60 & $75 \%$ \\
\hline 2 & Baik & 10 & $12,5 \%$ \\
\hline 3 & Cukup Baik & 5 & $6,25 \%$ \\
\hline 4 & Tidak Baik & 5 & $6,25 \%$ \\
\hline 5 & Sangat Tidak Baik & 0 & $0 \%$ \\
\hline & Jumlah & 80 & $100 \%$ \\
\hline
\end{tabular}

Sumber : Data diolah Tahun 2018

Tabel 4. Tanggapan responden tentang berpakaiannya seorang Customer Service.

\begin{tabular}{|c|c|c|c|}
\hline No & Keterangan & Jumlah & Presentase \\
\hline 1 & Sangat Baik & 40 & $50 \%$ \\
\hline 2 & Baik & 15 & $18,75 \%$ \\
\hline 3 & Cukup Baik & 15 & $18,75 \%$ \\
\hline 4 & Tidak Baik & 10 & $12,5 \%$ \\
\hline 5 & Sangat Tidak Baik & 0 & $0 \%$ \\
\hline & Jumlah & 80 & $100 \%$ \\
\hline
\end{tabular}

Sumber: Data diolah Tahun 2018

Berdasarkan tabel 5 di bawah dengan jumlah 80 responden dapat diketahui bahwa $50 \%$ (40 responden) yang menyatakan sangat baik, $18,75 \%$ (15 responden) yang menyatakan baik, $18,75 \%$ (15 responden) yang menyatakan cukup baik dan $12,5 \%$ (10 responden) yang menyatakan tidak baik terhadap tata rias wajah, rambut dan aksesories oleh seorang Customer Service hal ini perlu ditingkatkan lagi agar responden merasa nyaman. 
Tabel 5. Tanggapan responden tentang tata rias wajah, rambut dan aksesoris yang sedang digunakan seorang Customer Service.

\begin{tabular}{|c|c|c|c|}
\hline No & Keterangan & Jumlah & Presentase \\
\hline 1 & Sangat Baik & 40 & $50 \%$ \\
\hline 2 & Baik & 15 & $18,75 \%$ \\
\hline 3 & Cukup Baik & 15 & $18,75 \%$ \\
\hline 4 & Tidak Baik & 10 & $12,5 \%$ \\
\hline 5 & Sangat Tidak Baik & 0 & $0 \%$ \\
\hline & Jumlah & 80 & $100 \%$ \\
\hline
\end{tabular}

Sumber : Data diolah Tahun 2018

\section{Reliability (Keandalan)}

Berdasarkan tabel 6 dengan jumlah 80 responden dapat diketahui bahwa $83,75 \%$ (67 responden) yang menyatakan sangat baik dan $16,25 \%$ (13 responden) yang menyatakan sangat baik, terhadap Customer Service yang memiliki wawasan luas mengenai perbankan pada PT Bank Rakyat Indonesia (Persero) Tbk, Kantor Cabang Pembantu Kayu Tangi Banjarmasin.
Bedasarkan tabel 7 dengan jumlah 80 responden dapat diketahui bahwa 80\% (64 responden) yang menyatakan sangat baik, $16,25 \%$ (13 responden) yang menyatakan baik, $3,75 \%$ (3 responden) yang menyatakan cukup baik terhadap kemampuan dalam menjelaskan produk dan jasa yang telah di tawarkan oleh seorang Customer Service pada PT Bank Rakyat Indonesia (Persero) Tbk, Kantor Cabang Pembantu Kayu Tangi Banjarmasin.

Tabel 6. Tanggapan responden tentang seorang Customer Service yang memiliki wawasan luas mengenai perbankan.

\begin{tabular}{|c|c|c|c|}
\hline No & Keterangan & Jumlah & Presentase \\
\hline 1 & Sangat Baik & 67 & $83,75 \%$ \\
\hline 2 & Baik & 13 & $16,25 \%$ \\
\hline 3 & Cukup Baik & 0 & $0 \%$ \\
\hline 4 & Tidak Baik & 0 & $0 \%$ \\
\hline 5 & Sangat Tidak Baik & 0 & $0 \%$ \\
\hline & Jumlah & 80 & $100 \%$ \\
\hline
\end{tabular}

Sumber : Data diolah Tahun 2018

Tabel 7. Tanggapan responden tentang Customer Service memiliki kemampuan dalam menjelaskan produk dan jasa yang ditawarkan.

\begin{tabular}{|c|c|c|c|}
\hline No & Keterangan & Jumlah & Presentase \\
\hline 1 & Sangat Baik & 64 & $80 \%$ \\
\hline 2 & Baik & 13 & $16,25 \%$ \\
\hline 3 & Cukup Baik & 3 & $3,75 \%$ \\
\hline 4 & Tidak Baik & 0 & $0 \%$ \\
\hline 5 & Sangat Tidak Baik & 0 & $0 \%$ \\
\hline & Jumlah & 80 & $100 \%$ \\
\hline
\end{tabular}

Sumber : Data diolah Tahun 2018

Berdasarkan tabel 8 dengan jumlah 80 responden dapat diketahui bahwa $67,5 \%$ (54 responden) yang menyatakan sangat baik, $13,75 \%$ (11 responden) yang menyatakan baik dan $18,75 \% \quad(15$ responden) yang menyatakan cukup baik tentang seorang Customer Service memberikan solusi atas keluhan yang dirasakan oleh nasabah perbankan bahwa $18,75 \%$ responden menyatakan cukup baik pada pelayanan di Bank BRI KCP Kayu Tangi Banjarmasin. 
Tabel 8. Tanggapan responden tentang memberikan solusi atas keluhan yang dirasakan

\begin{tabular}{|c|c|c|c|}
\hline No & Keterangan & Jumlah & Presentase \\
\hline 1 & Sangat Baik & 54 & $67,5 \%$ \\
\hline 2 & Baik & 11 & $13,75 \%$ \\
\hline 3 & Cukup Baik & 15 & $18,75 \%$ \\
\hline 4 & Tidak Baik & 0 & $0 \%$ \\
\hline 5 & Sangat Tidak Baik & 0 & $0 \%$ \\
\hline & Jumlah & 80 & $100 \%$ \\
\hline
\end{tabular}

Sumber : Data diolah Tahun 2018

\section{Responsiveness (Daya Tanggap)}

Berdasarkan tabel 9 dengan jumah 80 responden dapat diketahui bahwa $68,75 \%$ (55 reponden) yang menyatakan sangat baik, $21,25 \%$ (17 responden) yang menyatakan baik, 3,75\% (3 responden) yang menyatakan cukup baik dan $6,25 \%$ (5 responden) yang menyatakan tidak baik, tentang seorang Customer Service yang pelayanan awal nya menyambut nasabah, memberikan senyuman, salam, serta mempersilahkan duduk pada saat nasabah datang, hal ini dapat disimpulkan bahwa Customer Service masih harus memperbaiki aspek sikap percaya diri dalam melayani nasabah.

Berdasarkan tabel 10 dengan jumlah 80 responden dapat diketahui bahwa 18,75\% (15 responden) yang menyatakan sangat baik, 47,5\% (38 responden) yang menyatakan baik, $22,5 \%$ (18 responden) yang menyatakan cukup baik dan $11,25 \%$ (9 responden) yang menyatakan tidak baik. Jadi, pada bagian ini perlu ditingkatkan lagi.

Tabel 9. Tanggapan responden tentang Customer Service berdiri menyambut nasabah, memberi senyum, salam, dan serta mempersilahkan nasabah duduk.

\begin{tabular}{|c|c|c|c|}
\hline No & Keterangan & Jumlah & Presentase \\
\hline 1 & Sangat Baik & 55 & $68,75 \%$ \\
\hline 2 & Baik & 17 & $21,25 \%$ \\
\hline 3 & Cukup Baik & 3 & $3,75 \%$ \\
\hline 4 & Tidak Baik & 5 & $6,25 \%$ \\
\hline 5 & Sangat Tidak Baik & 0 & $0 \%$ \\
\hline & Jumlah & 80 & $100 \%$ \\
\hline
\end{tabular}

Sumber : Data diolah Tahun 2018

Tabel 10. Tanggapan responden tentang melaksanakan pelayanan dengan cepat dan tepat.

\begin{tabular}{|c|c|c|c|}
\hline No & Keterangan & Jumlah & Presentase \\
\hline 1 & Sangat Baik & 15 & $18,75 \%$ \\
\hline 2 & Baik & 38 & $47,5 \%$ \\
\hline 3 & Cukup Baik & 18 & $22,5 \%$ \\
\hline 4 & Tidak Baik & 9 & $11,25 \%$ \\
\hline 5 & Sangat Tidak Baik & 0 & $0 \%$ \\
\hline & Jumlah & 80 & $100 \%$ \\
\hline
\end{tabular}

Sumber : Data diolah Tahun 2018

Berdasarkan tabel 11 dengan jumlah 80 responden dapat diketahui bahwa $62,5 \%$ (50 responden) yang menyatakan sangat baik, $18,75 \%$ (15 responden) yang menyatakan baik, 5\% (4 responden) yang menyatakan cukup baik dan $13,75 \%$ (11 responden) yang menyatakan tidak baik. Dengan demikian dapat dikumpulkan bahwa $13,75 \%$ tentang seorang Customer Service yang kurang membantu dalam mengisi formulir dan mengumpulkan kelengkapan persyaratan nasabah agar dipertingkatkan lagi. 
Tabel 11. Tanggapan responden tentang membantu nasabah.

\begin{tabular}{|c|c|c|c|}
\hline No & Keterangan & Jumlah & Presentase \\
\hline 1 & Sangat Baik & 50 & $62,5 \%$ \\
\hline 2 & Baik & 15 & $18,75 \%$ \\
\hline 3 & Cukup Baik & 4 & $5 \%$ \\
\hline 4 & Tidak Baik & 11 & $13,75 \%$ \\
\hline 5 & Sangat Tidak Baik & 0 & $0 \%$ \\
\hline & Jumlah & 80 & $100 \%$ \\
\hline
\end{tabular}

Sumber : Data diolah Tahun 2018

\section{Assurance (Jaminan)}

Berdasarkan tabel 12 dengan jumlah 80 responden dapat diketahui bahwa 62,5\% (50 responden) yang menyatakan sangat baik, $12,5 \%$ (10 responden) yang menyatakan baik, dan $25 \%$ (20 responden) menyatakan cukup baik. Dengan demikian dapat dikumpulkan bahwa $18,75 \%$ responden pada bagian ini perlu ditingkatkan lagi untuk mencapai kepuasan nasabah.
Berdasarkan tabel 13 dengan jumlah 80 responden dapat diketahui bahwa $56,25 \%$ (45 responden) menyatakan sangat baik, $18,75 \%$ (15 responden) yang menyatakan baik, dan $25 \%$ (20 responden) menyatakan cukup baik. Pada bagian ini perlu ditingkatkan lagi agar nasabah lama dan baru tetap menabung di Bank tersebut.

Tabel 12. Tanggapan responden tentang meyakinkan bahwa aman menjadi nasabah.

\begin{tabular}{|c|c|c|c|}
\hline No & Keterangan & Jumlah & Presentase \\
\hline 1 & Sangat Baik & 50 & $62,5 \%$ \\
\hline 2 & Baik & 10 & $12,5 \%$ \\
\hline 3 & Cukup Baik & 20 & $25 \%$ \\
\hline 4 & Tidak Baik & 0 & $0 \%$ \\
\hline 5 & Sangat Tidak Baik & 0 & $0 \%$ \\
\hline & Jumlah & 80 & $100 \%$ \\
\hline
\end{tabular}

Sumber : Data diolah Tahun 2018

Tabel 13. Tanggapan responden tentang memberi jaminan terhadap pelayanan yang nyaman, tepat, dan teliti.

\begin{tabular}{|c|c|c|c|}
\hline No & Keterangan & Jumlah & Presentase \\
\hline 1 & Sangat Baik & 45 & $56,25 \%$ \\
\hline 2 & Baik & 15 & $18,75 \%$ \\
\hline 3 & Cukup Baik & 20 & $25 \%$ \\
\hline 4 & Tidak Baik & 0 & $0 \%$ \\
\hline 5 & Sangat Tidak Baik & 0 & $0 \%$ \\
\hline & Jumlah & 80 & $100 \%$ \\
\hline
\end{tabular}

Sumber : Data diolah Tahun 2018

Tabel 14. Tanggapan responden tentang memberi janji waktu penyelesaian masalah dan menepatinya kepada nasabah.

\begin{tabular}{|c|c|c|c|}
\hline No & Keterangan & Jumlah & Presentase \\
\hline 1 & Sangat Baik & 43 & $53,75 \%$ \\
\hline 2 & Baik & 20 & $25 \%$ \\
\hline 3 & Cukup Baik & 17 & $21,25 \%$ \\
\hline 4 & Tidak Baik & 0 & $0 \%$ \\
\hline 5 & Sangat Tidak Baik & 0 & $0 \%$ \\
\hline & Jumlah & 80 & $100 \%$ \\
\hline
\end{tabular}

Sumber : Data diolah Tahun 2018 
Berdasarkan tabel 14 di atas dengan jumlah 80 responden dapat diketahui bahwa $53,75 \%$ (43 responden) yang menyatakan sangat baik, 25\% (20 responden) yang menyatakan baik, dan 21,25\% (17 responden) yang menyatakan cukup baik. Jadi, pada bagian ini perlu ditingkatkan lagi.

\section{Empathy (Empati)}

Berdasarkan tabel 15 dengan jumlah 80 responden dapat diketahui bahwa 56,25\% (45 responden) yang menyatakan sangat baik, $7,5 \%$ (6 responden) yang menyatakan baik dan 36,25\% (29 responden) menyatakan tidak baik tentang cara seorang Customer Service mendengarkan komplain nasabah dengan sungguh-sungguh hal ini perlu di tingkatkan lagi.

Tabel 15. Tanggapan responden tentang mendengarkan komplain nasabah dengan sungguh-sungguh.

\begin{tabular}{|c|c|c|c|}
\hline No & Keterangan & Jumlah & Presentase \\
\hline 1 & Sangat Baik & 45 & $56,25 \%$ \\
\hline 2 & Baik & 6 & $7,5 \%$ \\
\hline 3 & Cukup Baik & 29 & $36,25 \%$ \\
\hline 4 & Tidak Baik & 0 & $0 \%$ \\
\hline 5 & Sangat Tidak Baik & 0 & $0 \%$ \\
\hline & Jumlah & 80 & $100 \%$ \\
\hline
\end{tabular}

Sumber : Data diolah Tahun 2018

Tabel 16. Tanggapan responden tentang Customer Service meminta maaf atas setiap komplain dan ketidaknyamanan yang diajukan oleh nasabah.

\begin{tabular}{|c|c|c|c|}
\hline No & Keterangan & Jumlah & Presentase \\
\hline 1 & Sangat Baik & 52 & $65 \%$ \\
\hline 2 & Baik & 6 & $7,5 \%$ \\
\hline 3 & Cukup Baik & 12 & $15 \%$ \\
\hline 4 & Tidak Baik & 10 & $12,5 \%$ \\
\hline 5 & Sangat Tidak Baik & 0 & $0 \%$ \\
\hline & Jumlah & 80 & $100 \%$ \\
\hline
\end{tabular}

Sumber : Data diolah Tahun 2018

Tabel 17. Tanggapan responden tentang ucapan salam terima kasih dan salam di akhir layanan.

\begin{tabular}{|c|c|c|c|}
\hline No & Keterangan & Jumlah & Presentase \\
\hline 1 & Sangat Baik & 45 & $56,25 \%$ \\
\hline 2 & Baik & 10 & $12,5 \%$ \\
\hline 3 & Cukup Baik & 25 & $31,25 \%$ \\
\hline 4 & Tidak Baik & 0 & $0 \%$ \\
\hline 5 & Sangat Tidak Baik & 0 & $0 \%$ \\
\hline & Jumlah & 80 & $100 \%$ \\
\hline
\end{tabular}

Sumber : Data diolah Tahun 2018

Berdasarkan tabel 16 dengan jumlah 80 responden dapat diketahui bahwa 65\% (52 responden) yang menyatakan sangat baik, 7,5\% (6 responden) yang menyatakan, 15\% (12 responden) menyatakan cukup baik, dan $12,5 \%$ (10 responden) yang menyatakan tidak baik tentang cara seorang Customer Service meminta maaf atas kesalahan setiap komplain dan keluhan nasabah, hal ini perlu ditingkatkan lagi.

Berdasarkan tabel 17 dengan jumlah 80 responden dapat diketahui bahwa $56,25 \%$ (45 responden) yang menyatakan sangat baik, $12,5 \%$ (10 responden) yang menyatakan baik dan $31,25 \%$ (25 responden) menyatakan cukup baik. Perlu ditingkatkan lagi agar nasabah merasa nyaman pada PT Bank 
Rakyat Indonesia (Persero) Tbk, Kantor Cabang Pembantu Kayu Tangi Banjarmasin.

Berdasarkan penyebaran kuesioner kepada nasabah sebanyak dapat disimpulkan hal-hal yang menyebabkan ketidakpuasan responden.

Hasil penelitian memperlihatkan sebagian besar 50\% (40 responden) yang menyatakan sangat baik namun masih ada yang menilai tidak baik $12,5 \%$ (10 responden). Pada poin ketelitian ini dibagian Customer Service dalam kemampuan dalam menjelaskan produk dan jasa yang telah di tawarkan oleh seorang Customer Service, sebagian besar 80\% (64 responden) yang menyatakan sangat baik dan 3,75\% (3 responden) yang menyatakan cukup. Hasil penelitian ini dapat dilihat dari responden diketahui bahwa $62,5 \%$ (50 responden) yang menyatakan sangat baik dan 13,75\% (11 responden) yang menyatakan tidak baik. Hasil penelitian ini memperlihatkan sebagian besar responden menyatakan baik $65 \% \quad$ (52 responden) dan 12,5\% (10 responden) yang menyatakan tidak baik tentang cara seorang Customer Service meminta maaf atas kesalahan setiap komplain dan keluhan nasabah, hal ini perlu ditingkatkan lagi. Hasil penelitian memperlihatkan sebagian besar jaminan pada penelitian ini berjumlah $56,25 \%$ (45 responden) menyatakan sangat baik dan 25\% (20 responden) menyatakan cukup baik, dapat dilihat dari pemberian solusi atas suatu permasalahan secara terinci sehingga nasabah dapat memahami penjelasan dari Customer Service sehingga nasabah merasa puas. semakin paham terhadap jaminan yang diberikan oleh bank tentu akan semakin tinggi kepuasan nasabah.

Berdasarkan konsep Tangible, Empathy, Reability, responsivess, Assurance ini dapat didefinisikan aspek-aspek layanan dibagian Customer Service yang telah memuaskan nasabah. Oleh karena itu, harus dipertahankan kembali kualitas pelayanan Customer Service sebab dari penelitian tersebut banyak berapa aspek yang kurang memadai atau kurang suka. Adapun aspekaspek yang masih harus ditingkatkan kembali untuk meningkatkan minat nasabah, yaitu:

1) Tangible (bukti fisik)

Tangible (bukti fisik) berpengaruh terhadap kepuasan nasabah. Bukti fisik merupakan wujud dari layanan dibagian Customer Service pada PT. Bank Rakyat Indonesia (persero), Tbk Kantor Cabang Pembantu Kayu Tangi Banjarmasin seperti tersedianya ruangan yang rapi, bersih, peralatan dan kenyaman nasabah.

2) Reliability (keandalan)

Reliability (keandalan) tidak berpengaruh terhadap kepuasan nasabah. Keandalan merupakan kemampuan dalam menjelaskan produk dan jasa pada PT. Bank Rakyat Indonesia (persero), Tbk Kantor Cabang Pembantu Kayu Tangi Banjarmasin dengan tepat, dapat dipercaya sesuai yang dijanjikan tanpa ada kesalahan kepada nasabahnya.

3) Responsiveness (daya tanggap)

Responsiveness berpengaruh terhadap kepuasan nasabah. Daya tanggap merupakan kemauan atau keinginan para karyawan PT. Bank Rakyat Indonesia (persero) Tbk, Kantor Cabang Pembantu Kayu Tangi Banjarmasin untuk memberikan jasa yang dibutuhkan nasabah.

4) Empathy (empati)

Empaty berpengaruh terhadap kepuasan nasabah. Empathy merupakan sikap kontak PT. Bank Rakyat Indonesia (persero), Tbk Kantor Cabang Pembantu Kayu Tangi Banjarmasin dalam memenuhi kebutuhan dan kesulitan konsumen, komukikasi yang baik, perhatian pribadi, dan kemudahan untuk melakukan komunikasi. Empathy pada 
penelitian ini adalah tanggapan tehadap keluhan yang disampaikan oleh nasabah.

5) Assurance (jaminan)

Assurance berpengaruh terhadap kepuasan nasabah. Jaminan yang mencakup pengetahuan dan keramahan para karyawan dan kemampuan mereka untuk menimbulkan kepercayaan dan keyakinan oleh PT Bank Rakyat Indonesia (persero) Tbk, Kantor Cabang Pembantu Kayu Tangi Banjarmasin.

Analisis Permasalahan

Analisis permasalahan terhadap responden dapat ditemukan beberapa pelayanan yang diberikan oleh Customer Service masih belum memuaskan nasabah pada PT Bank Rakyat Indonesia (Persero) Tbk, Kantor Cabang Pembantu Kayu Tangi Banjarmasin.

Kekurangan yang ada harus dijadikan sebuah pembelajaran yang berharga pada PT Bank Rakyat Indonesia (Persero) Tbk, Kantor Cabang Pembantu Kayu Tangi Banjarmasin agar dapat dijadikan sumber masukan dan pertimbangan dalam upaya memperbaiki serta meningkatkan sehingga bisa mempertahankan kinerja selama ini yang telah berjalan.

Tanggapan responden terhadap berpakaian seragam bersih dan rapi seorang Customer Service dalam berpakaian haruslah mampu menjaga kerapian dan kebersihan dalam berpakaian saat memberikan pelayanan dan membuat nasabah merasa nyaman ketikat melihat dan berada pada kantor tersebut. Tanggapan responden seorang Customer Service dalam memberikan solusi atas keluhan yang dirasakan nasabahnya. Customer Service harus lebih baik dalam memberikan solusi atas keluhan agar nasabah tidak komplen dan merasa puas. Tanggapan responden terhadap Customer Service cepat tanggap terhadap masalah yang disampaikannya. Customer Service harus fokus apa yang dibicarakan nasabah.
Customer Service harus memberikan perhatian penuh kepada nasabah agar dapat memahami permasalahan dan tepat menanggapinya. Tanggapan responden terhadap keterampilan Customer Service dalam memasukkan data nasabah dengan benar. Customer Service harus teliti dalam memasukan data agar pengisian data benar tidak ada kesalahan.

Tanggapan responden terhadap kemampuan Customer Service dalam berkomunikasi dengan nasabah. Customer Service harus cakap dalam berbicara cepat, tepat, dan mampu berinteraksi kepada nasabah agar nasabah merasa nyaman dan puas saat berkomunikasi dengan Customer Service.

\section{KESIMPULAN}

Pengukuran kepuasan nasabah terhadap Customer Service pada PT Bank Rakyat Indonesia (Persero) Tbk, Kantor Cabang Pembantu Kayu Tangi Banjarmasin karena masih harus dikembangkan lagi karena terdapat beberapa kritik dari nasabah dari demensi servqual yaitu, Tangibel, Reliability,

Responsiveness, Assurance dan Empaty.

Tanggapan responden terhadap berpakaian seragam bersih dan rapi seorang Customer Service menunjukkan bahwa menjaga kerapian dan kebersihan dalam berpakaian saat memberikan pelayanan dan membuat nasabah merasa nyaman ketikat melihat dan berada pada kantor tersebut.

Tanggapan responden seorang Customer Service dalam memberikan solusi atas keluhan yang dirasakan nasabahnya menunjukkan bahwa Customer Service harus lebih baik dalam memberikan solusi atas keluhan agar nasabah tidak komplen dan merasa puas. 
Tanggapan responden terhadap pemberian solusi atas suatu permasalahan secara terinci sehingga nasabah paham menunjukkan bahwa komunikasi yang jelas terhadap pemberian solusi atas suatu permasalahan secara terinci sehingga nasabah dapat paham atas masalah yang dialaminya.

\section{DAFTAR PUSTAKA}

Basu Swastha, (2002:17). Manajemen

Pemasaran Modern, Yogyakarta,

Liberty Offset.

Bitner dan Zeithmal. (2003). Service Marketing. Tata McGraw Hill. New Delhi.

Daryanto, Ismanto Setyobudi. (2014).

Konsumen dan Pelayanan Prima.

Malang: Gaya Media.

Firda Khaina Safitri, B03120094 (2015),

Kepuasan Nasabah pada Bank BRI Banjarmasin.
Handi Novian Hadi Putra, B03130094 (2016), Strategi Meningkatkan Pelayanan Front Liner Terhadap Kepuasan Nasabah pada PT BTN Banjarmasin.

Harper W. dkk, (2000), Manajemen Pemasaran edisi 2 jilid 2, Jakarta, Erlangga

Kasmir, (2002). Bank dan Lembaga Keuangan Lainnya, PT. Raja Grafindo Persada. Jakarta.

Kasmir. (2006). Etika Customer Service. Penerbit PT. Raja Grafindo Persada. Jakarta.

Kotler, P. \& Keller, K.L. (2008). Manajemen Pemasaran, Edisi 12. Jilid 1. Alih Bahasa Benyamin Molan. Penerbit PT Indeks: Jakarta.

Parasuraman, (1994). Dimensi Serqual. Jurnal of Marketing Pemasaran http://eprints.uny.ac.id/8751/3/bab\%202 \%2009410131009.pdf

William B.Martin (2005), Quality Pelanggan Service. Victory Jaya Abadi. 